\title{
Cornélio Pires E Monteiro Lobato: da esperança à melancolia, o debate sobre o progresso
}

\author{
Emiliano Rivello Alves \\ Orientador: Mariza Veloso Motta Santos \\ Tese de Doutorado \\ Data da defesa: 29.06.2012
}

\begin{abstract}
ste trabalho estuda as trajetórias intelectuais de Cornélio Pires e Monteiro Lobato, nos anos de 1900-1940. Importa discutir suas visões sobre o progresso brasileiro em um contexto de franca transformação social. Esses autores estabelecem distinções na maneira de se pensar a pátria. Nascidos na República, contemplando a abolição da escravidão, o processo de urbanização e os debates sobre modernização social refletem os dilemas do campo intelectual engajado em dar respostas às necessidades mais prementes da modernidade. Cornélio Pires, um autor de formação e origem eminentemente popular, procura valorizar a figura do nacional, do caipira e sua cultura, porque entende ser essencial ao futuro do país integrar populações à margem da modernidade. Trata-se de uma proposta que humaniza a célebre figura malfadada de Jeca Tatu. Monteiro Lobato, um intelectual da mais alta estirpe, percebe, no sitiante do campo, o estado vegetativo do homem, da indolência e da preguiça - uma população débil que se contrapõe ao progresso. Para escapar dessa realidade grotesca e desigual alude romper com a tradição e a cultura popular, permitindo ao país ascender à modernidade. Ambos postulam proeminência no campo intelectual, além de ocuparem com desenvoltura posições no âmbito da cultura, da atuação pública, artística e editorial. Contudo, ao final da vida experimentam a solidão literária motivada pelo avanço do movimento modernista. Aparentemente desiludidos com os rumos do país, projetam uma visão resignada e pessimista em relação à cultura nacional. Sinal de que o Brasil não havia encontrado a saída de suas mazelas.
\end{abstract}

Palavras-chave: Progresso, Modernidade, Representações, Caipira, Cornélio Pires, Monteiro Lobato. 